\title{
Cardiac implications of amlodipine-dantrolene combinations
}

M. Freysz MD PhD,* Q. Timour PhD, $†$ C. Bernaud MD, $\ddagger$ L. Bertrix MD PhD, $\dagger$ G. Faucon MD PhD $\dagger$
Purpose: Cardiac disorders, cardiac arrest and ventricular fibrillation in the most severe cases, have been observed after the administration of dantrolene to patients treated by verapamil for coronary artery disease. This study was designed to examine the interaction of dantrolene with amlodipine, a dihydropyridine.

Methods: In 12 anaesthetized, open-chest pigs, the effects of the interaction have been studied on heart rate, atrioventricular conduction, monophasic action potential duration, intraventricular conduction time, left ventricular $d P / d t$ max and mean blood pressure. The study was performed with normal coronary circulation and ischaemia of a large area of the left ventricule, obtained by complete occlusion of the left anterior descending coronary artery near its origin, under pacing at a constant high rate, 180 beats $\cdot \mathrm{min}^{-1}$. The drugs were injected iv, amlodipine $0.4 \mathrm{mg} \cdot \mathrm{kg}^{-1}$ first and dantrolene $3.0 \mathrm{mg} \cdot \mathrm{kg}^{-1}$ 20 min later in six animals and the order was reversed in the other animals.

Results: Sinus rate and atrioventricular conduction were not affected by amlodipine, but were slowed by dantrolene added (145 \pm 9 to $131 \pm 7$ beats $\cdot \mathrm{min}^{-1}, P<0.01$ and $150 \pm 15$ to $180 \pm 20 \mathrm{msec}, P<0.01)$. In contrast, amlodipine or amlodipine plus dantrolene did not change MAP duration or conduction time in the normal heart. Similarly, they did not alter the maximal variations due to ischaemia, but delayed them, while prolonging the time to onset of fibrillation $(11) \pm 8$ to $343 \pm$ $33 \mathrm{sec}, P<0.001$ with amlodipine alone, $289 \pm 11$ to $323 \pm$ $16 \mathrm{sec}, P<0.05$ with dantrolene). Left ventricular $d P / d t$ max was lowered from $1670 \pm 86$ to $1532 \pm 50 \mathrm{mmHg} \cdot \mathrm{sec}^{-1}(P<$

\section{Key words}

HEART: ventricular arrhythmias, calcium channel; HYPERTHERMIA: malignant hyperthermia; PHARMACOLOGY: amlodipine dantrolene; IONS: potassium.

From the Department of Anesthesiology and Intensive Care, General Hospital*, F-21033 Dijon Cedex. Department of Medical Pharmacology, Claude Bernard University $\dagger$, F-69373 Lyon Cedex 08. Laboratoire Pfizerł, F-91407 Orsay Cedex.

Address correspondence to: Dr. Freysz, Department of Anesthesiology and Intensive Care, General Hospital, F21033 Dijon Cedex, France.

Accepted for publication 31st August, 1995.
$0.001)$ and mean blood pressure from $79 \pm 4$ to $70 \pm 3 \mathrm{mmHg}$ $(P<0.0 I)$ by amlodipine, but dantrolene did not enhance and even counteracted these effects. Finally, potassium plasma concentration did not increase above $5.1 \pm 0.2 \mathrm{mmol} \cdot \mathrm{L}^{-1}$ under the dual influence of amlodipine and dantrolene.

Conclusion: In usual clinical doses, dantrolene may be safely administered concurrently with amlodipine.

Objectifs: Des troubles cardiaques, arrêt cardiaque et fibrillation ventriculaire dans les cas les plus graves, ont été observés après administration de dantrolène à des patients traités par le vérapamil pour coronarite. Les interactions entre le dantrolène et une dihydropyridine, l'amlodipine, font l'objet de cette étude.

Méthodes: Chez 12 porcs anesthésiés, à thorax ouvert, les effets de cette association ont été étudiés sur le rythme cardiaque, la conduction. auriculoventriculaire, la durée du potentiel d'action monophasique (MAP), le temps de conduction intraventriculaire, dP/dt max ventriculaire gauche et la pression artérielle moyenne. L'élude a été réalisée avec circulation coronaire normale et ischémie d'une aire importante du ventricule gauche, obtenue par occlusion complète de l'artère interventriculaire antérieure près de son origine, sous pacing à rythme constant élevé, 180 battements $\cdot \mathrm{min}^{-1}$. Les produits ont été injectés par voie veineuse, l'amlodipine à la dose de $0.4 \mathrm{mg} \cdot \mathrm{kg}^{-1}$ d'abord et le dantrolène à la dose de $3.0 \mathrm{mg} \cdot \mathrm{kg}^{-1}$ 20 minutes plus tard chez six animaux et vice versa chez les six autres.

Résultats: Le rythme sinusal et la conduction auriculoventriculaire n'ont pas été affectés par l'amlodipine, mais ralentis par le dantrolène ajouté ( $145 \pm 9$ à $13 I \pm 7$ battements. min $^{-1}$, $P<0.01$ et $150 \pm 15$ à $180 \pm 20$ msec, $P<0.01$ ). En revanche, l'amlodipine ou l'amlodipine plus le dantrolène n'ont pas modifié la durée du MAP ni le temps de conduction sur le coeur normal. De façon similaire, rien n'a été changé dans les variations maximales dues à l'ischémie, si ce n'est qu'elles ont été retardées, tandis qu'était prolongé le temps de déclenchement de la fibrillation $(J /) \pm 8$ à $343 \pm 33 \mathrm{sec}, P<$ 0.001 avec l'amlodipine seule, $289 \pm 1 /$ à $323 \pm 16 \mathrm{sec}, P<$ 0.05 avec le dantrolène). $d P / d t$ max ventriculaire gauche fut abaissé de $1670 \pm 86$ à $1532 \pm 50 \mathrm{mmHg} \cdot \mathrm{sec}^{-1}(P<0.001)$ et la pression artérielle moyenne de $79 \pm 4$ à $70 \pm 3 \mathrm{mmHg}(P<$ $0.01)$ par l'amlodipine, mais le dantrolène n'exagérait pas ou même contrariait ces effets. Enfin, la kaliémie ne s'élevait pas 
au-dessus de $5.1 \pm 0.2 \mathrm{mmol} \cdot L^{-1}$ sous la double influence de l'amlodipine et du danirolène.

Conclusion: Le dantrolène pourrait donc être administré concomitamment à l'amlodipine sans grand risque aux doses cliniques habituelles.

Calcium antagonists are widely used in the management of patients with coronary artery disease. They allow myocardial ischaemia to be tolerated better by preserving cardiac energy stores, due to their negative chronotropic and inotropic action. They also protect against ventricular fibrillation secondary to acute occlusion of a large coronary artery ${ }^{1-3}$ or to the acute increase in cardiac oxygen requirements in patients whose coronary flow is limited. ${ }^{4,5}$ Dantrolene is the drug which provides the best results in treating perioperative malignant hyperthermia. ${ }^{6}$ However, concurrent administration of verapamil and dantrolene leads to severe cardiac accidents such as cardiac arrest, atrioventricular block, acute heart failure or circulatory collapse, and ventricular fibrillation, these reactions being accompanied by hyperkalaemia up to $7.1 \mathrm{mmol} \cdot \mathrm{L}^{-1}$. These risks may be confirmed by the combined administration to animals. ${ }^{8,9}$ However, the cardiovascular effects of the various calcium antagonists are not identical. Dihydropyridines, such as nifedipine, do not appear to give rise to the same complications as verapamil when given with dantrolene. ${ }^{10}$ The aim of this study was to investigate, in animals, the cardiovascular effects resulting from the combined administration of dantrolene and amlodipine, a dihydropyridine almost devoid of negative chronotropic action and displaying only weak inotropic activity. These effects were investigated not only under normal coronary circulation, but also in the ischaemic heart, as most of the accidents caused by the verapamil-dantrolene combination were observed in patients suffering from coronary artery disease.

\section{Methods}

\section{Animals and preparation}

The experiments were conducted in 12 domestic pigs of either sex, about six weeks of age and weighing 24-30 $\mathrm{kg}$. After approval of the protocol by the Animal Care Committee, the animals were premedicated with 1.25 $\mathrm{mg} \cdot \mathrm{kg}^{-1}$ droperidol $\mathrm{im}$ one hour before the experiment and anaesthetized with $0.05 \mathrm{mg} \cdot \mathrm{kg}^{-1}$ flunitrazepam and $80 \mathrm{mg} \cdot \mathrm{kg}^{-1}$ chloralose iv via the marginal ear vein. Their lungs were ventilated with a PR2 respirator (Bennett, Santa Monica, CA, USA) through a tracheotomy tube. This respirator delivered an air-oxygen mixture (40 and $60 \%$ respectively): $\mathrm{PO}_{2}, \mathrm{PCO}_{2}$ and $\mathrm{pH}$ were kept within the ranges $80-200 \mathrm{mmHg}, 32-42 \mathrm{mmHg}$ and 7.35-7.50 respectively. Throughout the experiment, core temperature was measured by an electronic oesophageal thermometer and maintained between 37.5 and $39.0^{\circ} \mathrm{C}$ with an infrared heater placed at various distances from the animals.

In all pigs, the heart was exposed through a left-side thoracotomy with resection of the fourth and fifth ribs. The pericardium was then opened and the left anterior descending coronary artery was dissected close to its origin. A snare was passed around the artery to allow its complete occlusion to be achieved, when desired.

Periods of myocardial ischaemia were obtained by suddenly tightening the snare around the artery. Ischaemia involved an area of the left ventricule large enough to place within it one electrode to pace the heart electrically at a constant high rate, 180 beats $\cdot \min ^{-1}$, throughout the ischaemia period, and another electrode to record monophasic action potentials (MAP). The ischaemic area was defined as the cyanotic zone spreading from the artery almost to the central line of the anterior ventricular wall. The arterial occlusion was discontinued at the triggering of fibrillation which occurs ordinarily after one to three minutes of occlusion (time to onset of fibrillation or time to fibrillation). Defibrillation was carried out by one or several electric countershocks applied to the thoracic wall, using a Sirecard F defibrillator (Siemens, Erlangen, Germany). Sinus rate was generally restored in less than $15 \mathrm{sec}$.

\section{Monitoring of electrical and mechanical myocardial activity}

A surface ECG was recorded in all animals on a Mingograf 34 ECG (Elema-Schönander, Stockholm, Sweden) in a standard limb lead (especially II). The sinus rate was determined by the RR interval and the atrioventricular conduction time by the PR interval.

Local electrical activity was recorded through a Catronic ORX electrode $6 \mathrm{~F}$ (Plastimed, Saint-Leu-LaForêt, France), advanced within the subepicardial layer of the myocardial area intermittently subjected to ischaemia. Thus, the MAP could be continuously monitored on an EM 531 oscilloscope (Siemens, Erlangen, Germany) and registered on the ECG, whenever necessary, to measure its duration at $90 \%$ repolarization. Sinus control of ventricular beats was replaced intermittently, during short 10-15 sec periods, by ventricular pacing at a constant rate to avoid any change in MAP duration dependent on heart rate and to determine conduction time, the interval between the spike of stimulation and the steep upstroke of the MAP. Pacing was by means of a stimulating bipolar electrode positioned in the ischaemic area, in the vicinity of the recording elec- 
trode (one to two $\mathrm{cm}$ ). Impulses were delivered by an $S_{\text {I }}$ stimulator (Hugo Sachs, Freiburg im Brisgau, Germany) at a rate of 180 beats $\cdot \mathrm{min}^{-1}$ with $2 \mathrm{msec}$ duration and 1 mA strength.

Mechanical activity was monitored during the pacing periods on a Narcotrace 80 polygraph (NarcoBiosystem, Houston, TX, USA) using a catheter passed down from the right carotid artery to the left ventricle: left ventricle $\mathrm{dP} / \mathrm{dt} \max (\mathrm{LV} \mathrm{dP} / \mathrm{dt} \max$ ) was electronically derived by means of a physio-differentiator (Hugo Sachs, Freiburg im Brisgau, Germany) from the intraventricular pressure signal. Mean arterial blood pressure was recorded simultaneously on the polygraph through another catheter inserted into the left carotid artery.

\section{Experimental protocol}

The animals were divided into two groups of six. Animals in the first group were given amlodipine 0.4 $\mathrm{mg} \cdot \mathrm{kg}^{-1}$ and dantrolene $3.0 \mathrm{mg} \cdot \mathrm{kg}^{-1}$ iv 20 min later. Animals in the second group were given dantrolene 3.0 $\mathrm{mg} \cdot \mathrm{kg}^{-1}$ and amlodipine $0.4 \mathrm{mg} \cdot \mathrm{kg}^{-1} 20 \mathrm{~min}$ later.

In the control period, the variables were determined five minutes before the administration of amlodipine (first group) or dantrolene (second group) in the absence and presence of ischaemia and a blood sample was taken to determine potassium plasma concentration.

Subsequent measurements were made 5 to $20 \mathrm{~min}$ after the injection of amlodipine (first group) or dantrolene (second group) and 5, 20,35 and 60 min after the additional injection of dantrolene (first group) or amlodipine (second group).

\section{Statistics}

After a two-way (group and time) repeated measures analysis of variance (ANOVA) which did not show any significant variation, a paired Student's test was used to compare the values with amlodipine alone or with amlodipine plus dantrolene vs control values and, similarly, to compare the values with dantrolene alone and under dantrolene plus amlodipine vs control values. For most of the variables, comparisons were done in the absence and presence of ischaemia.

Results are expressed as mean \pm SEM and the differences are considered to be significant from $P<0.05$.

\section{Results}

\section{Effects of amlodipine and combined effects of amlodip-} ine and dantrolene

Amlodipine exerted no influence on sinus rate $(140 \pm 11$ to $145 \pm 9$ beats $\cdot \mathrm{min}^{-1}$ ), even in the high $0.4 \mathrm{mg} \cdot \mathrm{kg}^{-1}$ dose, whereas a moderate slowing ( $145 \pm 9$ to $131 \pm 7$ beats $\cdot \mathrm{min}^{-1}, P<0.01$ ) occurred with dantrolene (Figure

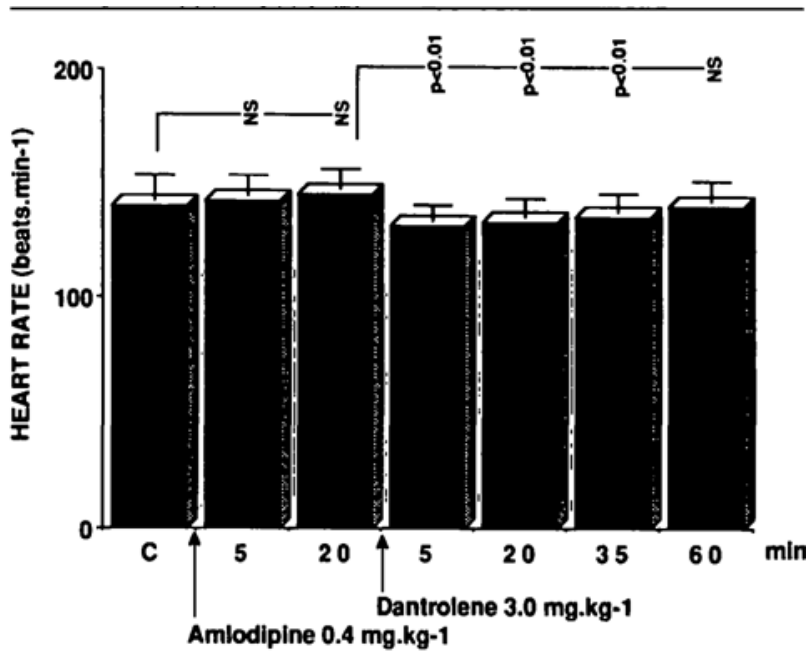

FIGURE I Comparison of amlodipine and dantrolene with amlodipine on sinus rate. Mean $\pm \mathrm{SEM}, n=6$.

1). Similarly, PR interval was not affected by amlodipine, but it increased from $150 \pm 15$ to $180 \pm 20 \mathrm{msec}(P$ $<0.01)$ after adding dantrolene. This increase was never sufficient to result in second or third degree heart blocks.

Ventricular pacing at a constant rate showed there was no change in MAP duration or intraventricular conduction timc attributable to amlodipine alone or to dantrolene associated to amlodipine. On the contrary, ischaemia reduced MAP duration (203 \pm 7 to $169 \pm 7$ msec, $P<0.00 \mathrm{I})$ and increased conduction time (41 \pm 2 to $56 \pm 4 \mathrm{msec}, P<0.001$ ). These maximal changes in MAP duration and conduction time induced by ischaemia were not different after amlodipine or amlodipine with dantrolene: they occurred only much later, as the time to onset of fibrillation was prolonged by amlodipine ( $111 \pm 8$ to $343 \pm 33 \mathrm{sec}, P<0.001$, five min after the injection (Figure 2), with a tendency to return to control values at $20 \mathrm{~min}(289 \pm 11, P<0.001)$. But the addition of dantrolene increased the time to fibrillation again to $323 \pm 16 \sec (P<0.05)$.

The LV dP/dt max decreased after amlodipine in both non-ischaemic $\left(1670 \pm 86\right.$ to $1532 \pm 50 \mathrm{mmHg} \cdot \mathrm{sec}^{-1}, P$ $<0.001)$ and ischaemic conditions (1485 \pm 81 to $1402 \pm$ $59 \mathrm{mmHg} \cdot \mathrm{sec}^{-1}, P<0.05$ ) (Figure 3 ). This decrease was antagonized by dantrolene, at least in the absence of ischaemia ( $1543 \pm 80$ to $1640 \pm 74 \mathrm{mmHg} \cdot \mathrm{sec}^{-1}, P<$ $0.001)$. Amlodipine was followed by a decrease of mean blood pressure, in the absence $(79 \pm 4$ to $70 \pm 3 \mathrm{mmHg}$, $P<0.01)$ as well as in the presence of ischaemia $(68 \pm 3$ to $63 \pm 3 \mathrm{mmHg}, \mathrm{P}<0.05$ ). This small decrease was not antagonized by dantrolene.

Amlodipine had no effect on plasma potassium con- 


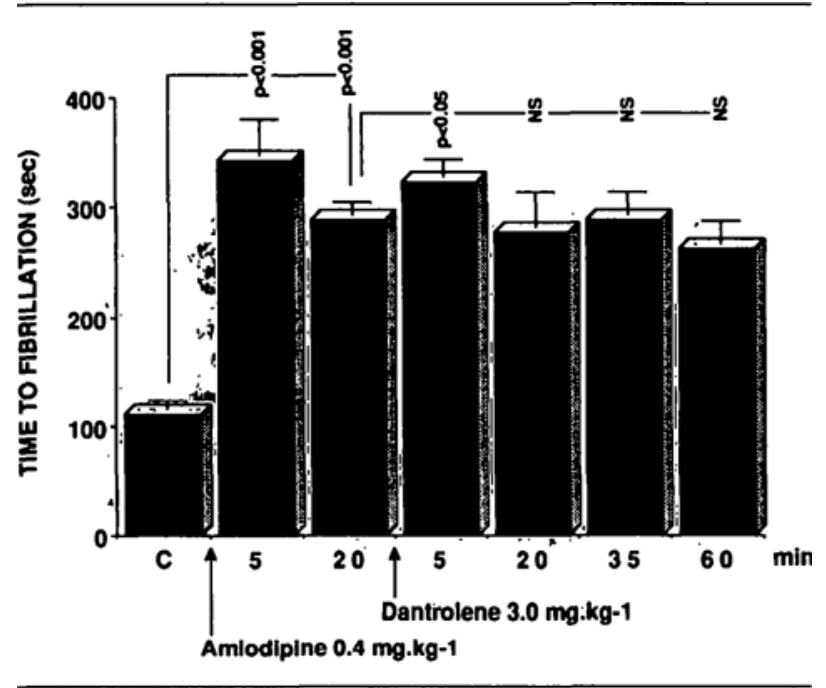

FIGURE 2 Comparison of amlodipinc and dantrolene with amlodipine on time to onset of fibrillation. Mcans $\pm \operatorname{SEM}, n=6$.

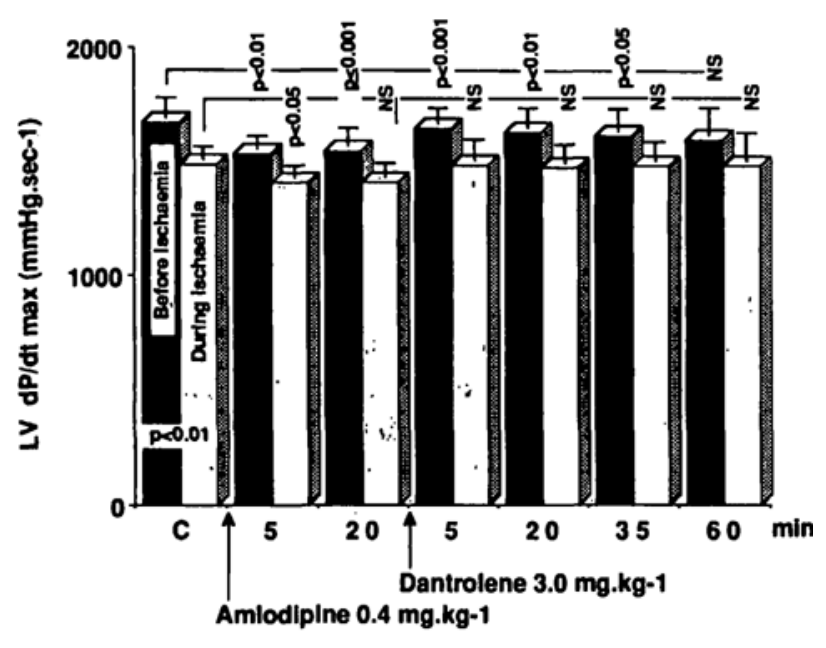

FIGURE 3 Comparison of amlodipine and dantrolene with amlodipine on left ventricular $\mathrm{dP} / \mathrm{d} t \max (\mathrm{LV} \mathrm{dP/dt} \max$ ) under pacing at a constant high ralc, 180 bcats $\cdot \min ^{-1}$, in the absence and presence of ischacmia. Means \pm SEM, $n=6$.

centration under normal conditions or after experimental ischaemia which increased this concentration from $4.0 \pm$ 0.1 to $4.4 \pm 0.1 \mathrm{mmol} \cdot \mathrm{L}^{-1}(P<0.001)$ (Figure 4$)$. On the contrary, the potassium concentration exhibited a further increase, from $4.5 \pm 0.1$ to $5.1 \pm 0.2 \mathrm{mmol} \cdot \mathrm{L}^{-1}$ $(P<0.01)$ after dantrolene. However, hyperkalaemia was modest in these experiments.

Effects of dantrolene and combined effects of dantrolene and amlodipine

Dantrolene administration was followed by slowing in

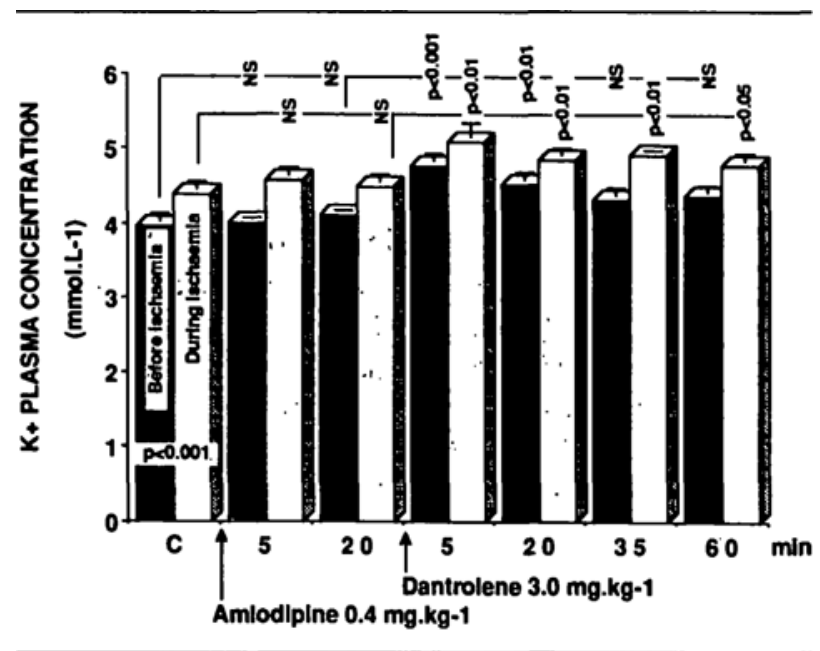

FIGURE 4 Comparison of amlodipine and dantrolene with amlodipinc on potassium plasma concentration in the absence and presence of ischaemia. Means \pm SEM, $n=6$

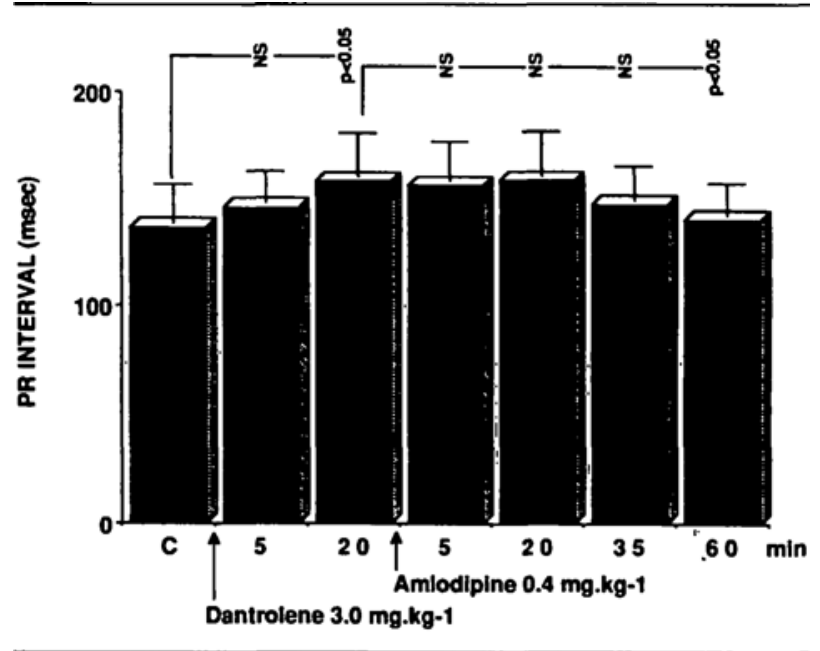

FIGURE 5 Comparison of dantrolene and amlodipine with dantrolene on atrioventricular conduction time. Means $\pm S E M, n=6$.

sinus rate $\left(166 \pm 13\right.$ to $147 \pm 11$ beats $\cdot \min ^{-1}, P<0.01$, at five minutes). This slowing was not enhanced by amlodipine. Likewise, the PR interval was prolonged by dantrolene, from $136 \pm 18$ to $158 \pm 21 \mathrm{msec}(P<0.05)$, without further lengthening by amlodipine (Figure 5 ).

Under constant rate ventricular pacing, no change occurred after dantrolene or dantrolene with amlodipine in the absence as well as in the presence of ischaemia, in MAP duration or conduction time which were respectively decreased from $200 \pm 7$ to $152 \pm 5 \mathrm{msec}(P<$ $0.001)$ and increased from $37 \pm 2$ to $55 \pm 3 \mathrm{msec}$ $(P<0.001)$ by ischaemia just before the triggering of fibrillation. However, time to fibrillation was increased 
by dantrolene alone, from $115 \pm 13$ to $165 \pm 25 \sec (P<$ 0.05 ), and much more by the dantrolene-amlodipine combination since it reached $422 \pm 54 \sec (P<0.01)$ five minutes after amlodipine injection.

The LV dP/dt max was not reduced by dantrolene before ischaemia (1555 \pm 108 to $1495 \pm 83$ $\mathrm{mmHg} \cdot \mathrm{sec}^{-1}$ at $20 \mathrm{~min}$ ), but was reduced during ischaemia (1308 \pm 96 to $1200 \pm 103 \mathrm{mmHg} \cdot \mathrm{sec}^{-1}, P<$ 0.05). Amlodipine added to dantrolene produced a further reduction (from $1200 \pm 103$ to $1.057 \pm 77$ $\mathrm{mmHg} \cdot \mathrm{sec}^{-1}, \quad P<0.05$, at five minutes) during ischaemia, as it decreased LV dP/dt max even before ischaemia (1495 \pm 83 to $1178 \pm 100 \mathrm{mmHg} \cdot \mathrm{sec}^{-1}, P<$ 0.05 ), but no change persisted at 20 min after injection. Dantrolene manifested a mild hypertensive action in the absence $(69 \pm 6$ to $76 \pm 7 \mathrm{mmHg}, P<0.05)$ as well as in the presence of ischaemia $(58 \pm 6$ to $66 \pm 8 \mathrm{mmHg}, P<$ 0.05) (Figure 6). Hypertension disappeared with the additional injection of amlodipine: the expected hypotensive effect of amlodipine was considerable, at least in the absence of ischaemia, since mean blood pressure decreased to $49 \pm 3 \mathrm{mmHg}(P<0.05)$.

Plasma potassium concentration increased after dantrolene, from $4.2 \pm 0.2$ to $4.7 \pm 0.2 \mathrm{mmol} \cdot \mathrm{L}^{-1}$ at 20 $\min (P<0.05)$, but was not influenced by amlodipine added to dantrolene. During ischaemia, the potassium concentration, higher than normal $(4.8 \pm 0.2$ instead of $\left.4.2 \pm 0.2 \mathrm{mmol} \cdot \mathrm{L}^{-1}, P<0.05\right) \mathrm{did}$ not increase further with the injection of dantrolene, alone or combined with amlodipine (except at five minutes, 4.9 to $5.1 \mathrm{mmol} \cdot \mathrm{L}^{-1}$, $P<0.05$ ).

\section{Discussion}

According to these experimental results, the risk of serious cardiac disturbances with the combination of amlodipine and dantrolene seems to be minor, even when amlodipine is administered in very high doses, 0.4 $\mathrm{mg} \cdot \mathrm{kg}^{-1}$. Contrary to the association of dantrolene and verapamil, ${ }^{7-9}$ severe impairment of myocardial contractility with circulatory collapse was not observed, the strength of ventricular beats being much less adversely affected by amlodipine than by verapamil. "In addition, the inhibition of the sinus node automaticity and atrioventricular conduction produced by verapamil is excluded with its replacement by amlodipine, which is recognized as having little influence on the sinus and atrioventricular nodes. ${ }^{11}$ Cardiac output is then almost unchanged and the variations of serum potassium are limited, since the hyperkalaemia to more than 7.0 $\mathrm{mmol} \cdot \mathrm{L}^{-1}$ reported with the combined administration of verapamil and dantrolene depends on the haemodynamic disorders. ${ }^{12.13}$ These changes may be sufficient to result in fatal accidents, given the possibility of a posi-

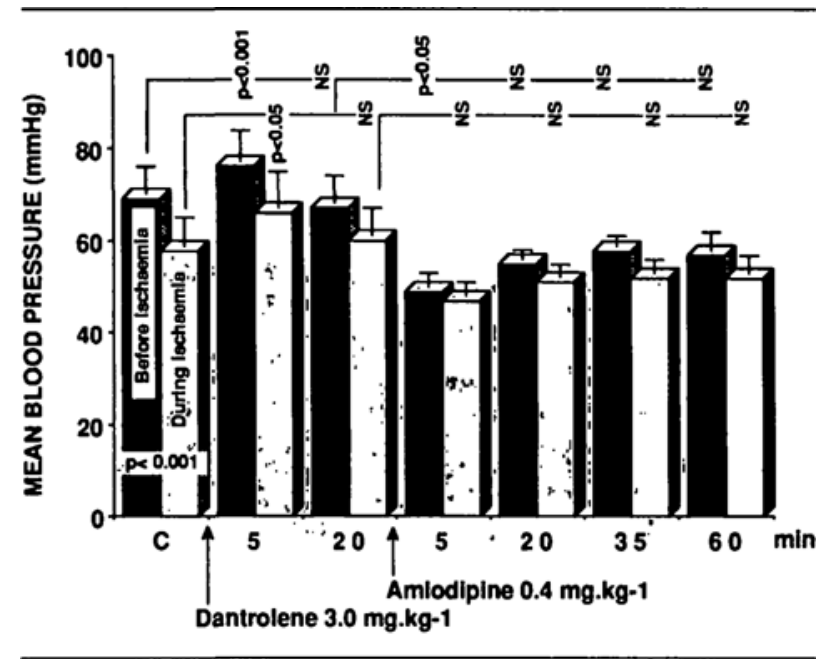

FIGURE 6 Comparison of dantrolene and amlodipinc with dantrolene on mean arterial blood pressurc in the absence and presence of ischaemia. Means $\pm \mathrm{SEM}, n=6$.

tive feed-back mechanism: reduction of cardiac output and organ perfusion induces hyperkalaemia that aggravates the depression of contractility. ${ }^{10}$

In fact, dantrolene added to amlodipine elicits only slight inhibition of the specialized atrial tissue, ${ }^{14}$ that was below the significance threshold in some investigations, ${ }^{15,16}$ and was possibly compensated by stimulation of the contractile ventricular tissue with a tendency to hypertension. Thus, the resulting hyperkalaemia is not sufficient to adversely affect haemodynamic variables. Dantrolene may antagonize hyperkalaemia, since it is thought to reduce the opening time of the ryanodine sensitive calcium channels in the skeletal muscles and, thereby, decrease the release of calcium from its storage sites in the sarcoplasmic reticulum, which is accompanied by an increased efflux of the cellular potassium. This behaviour is consistent with the reduction of muscular tone and metabolism that is responsible for the lowering of core temperature, ${ }^{17}$ which underlies the use of dantrolene in the treatment of malignant hyperthermia. ${ }^{6}$

The present investigations show also that, even in the presence of acute myocardial ischaemia, the association amlodipine-dantrolene is not a cause of cardiovascular impairment. Ischaemia might be assumed to take part in the genesis of the disorders reported with verapamil associated with dantrolene which generally occur in subjects treated by verapamil for coronary heart disease. Dantrolene tends to oppose rather than enhance the depression of myocardial contractility and the decrease of blood pressure due to the combined action of ischaemia and amlodipine, the influence of amlodipine being weak, in fact, on the ventricular contractions. Consequently, haemodynamic conditions are not dis- 
turbed appreciably and plasma potassium concentration does not increase substantially under the dual influence of dantrolene and amlodipine. Moreover, the ischaemiainduced reduction of MAP duration and slowing down of conduction immediately preceding ventricular fibrillation are delayed to a large extent by amlodipine and a little by dantrolene.

In conclusion, discontinuing treatment with calcium channel blockers in a patient with coronary heart disease is not recommended because of the risk of anginal attacks, sudden death or myocardial infarction. If such a patient develops malignant hyperthermia during anaesthesia, dantrolene is the drug liable to provide the best results. The association of a calcium antagonist and dantrolene is then unavoidable. In this situation, dihydropyridines, particularly amlodipine, are a good alternative to verapamil or diltiazem in association with dantrolene.

\section{References}

1 Brooks WW, Verrier RL, Lown B. Protective effect of verapamil on vulnerability to ventricular fibrillation during myocardial ischaemia and reperfusion. Cardiovasc Res 1980; 14: 295-302.

2 Surawicz B. Role of calcium-blocking agents in treatment of cardiac arrhythmias related to myocardial ischemia. Am Heart J 1982; 103: 698-706.

3 Clusin WT, Buchbinder M, Ellis AK, Kernoff RS, Giacomini JC, Harrison DC. Reduction of ischemic depolarization by the calcium channel blocker diltiazem. Circ Res 1984; 54: 10-20.

4 Aupetit JF, Timour Q. Chevrel G, Loufoua-Moundanga J, Omar $S$, Faucon $G$. Attenuation of the ischaemia-induced fall of electrical ventricular fibrillation threshold by a calcium antagonist, diltiazem. Naunyn-Schmiedeberg's Arch Pharmacol 1993; 348: 509-14.

5 Aupetit JF, Timour Q. Freysz $M$, et al. Vulnerability to ventricular fibrillation related to ischaemia: comparison of the acule effects of $\beta$-blockers and calcium antagonists. Arch Int Pharmacodyn 1994; 327: 25-39.

6 Kolb ME, Horne ML, Martz R. Dantrolene in human malignant hyperthermia. Anesthesiology 1982; 56: 254-62.

7 Rubin AS, Zablocki $A D$. Hyperkalemia, verapamil and dantrolene. Anesthesiology 1987; 66: 246-9.

8 Saltzman LS, Kates RA, Corke BC, Norfleet EA, Heath KR. Hyperkalaemia and cardiovascular collapse after verapamil and dantrolene administration in swine. Anesth Analg 1984; 63: 473-8.

9 Lynch C, Durbin CG Jr, Fisher NA, Veselis RA, Althaus $J S$. Effects of dantrolene and verapamil on atrioventricular conduction and cardiovascular performance in dogs. Anesth Analg 1986; 65: 252-8.
10 Henry PD. Comparative pharmacology of calcium antagonists: nifedipine, verapamil and diltiazem. Am J Cardiol 1980; 46: 1047-58.

11 Dodd MG, Gardiner DG, Carter AJ, Sutton MR, Burges $R A$. The haemodynamic propertics of amlodipine in anaesthetized and conscious dogs: comparison with nitrendipine and influence of beta-adrenergic blockade. Cardiovasc Drugs Ther 1989; 3: 545-55.

12 Nugent $M$, Tinker $J H$, Moyer TP. Verapamil worsens rate of development and hemodynamic effects of acute hyperkalemia in halothane-anesthetized dogs: effecis of calcium therapy. Anesthesiology 1984; 60: 435-9.

13 San Juan AC Jr, Wong KC, Port JD. Hyperkalemia after dantrolene and verapamil-dantrolene administration in dogs. Anesth Analg 1988; 67: 759-62.

14 Brooks RR, Carpenter JF, Jones SM, Gregory CM. Effects of dantrolene sodium in rodent models of cardiac arrhythmia. Eur J Pharmacol 1989; 164: 521-30.

15 Ellis KO; Wessels FL, Carpenter JF. Effects of intravenous dantrolene sodium on respiratory and cardiovascular functions. J Pharm Sci 1976; 65: 1359-64.

16 Pelleg A, Roth A, Shargordsky B, Belhassen B, Chagnac A, Laniado $S$. Effects of dantrolene sodium on occlusion and reperfusion arrhythmias in the canine heart. Methods Find Exp Clin Pharmacol 1985: 7:239-43.

17 Ohta T, Endo M, Nakano T, Morohoshi Y, Wanikawa $K$, Ohga A. Ca-induced $\mathrm{Ca}$ release in malignant hyperthermia-susceptible pig skeletal muscle. Am J Physiol 1989; 256: C358-67. 